\title{
Mouth preparation pasien hemangioma bibir pada anak sebelum tindakan radioterapi
}

\author{
*Irene Edith Rieuwpassa, **Harun Achmad \\ *Bagian Oral Biologi \\ **Bagian Ilmu Kedokteran Gigi Anak \\ Fakultas Kedokteran Gigi Universitas Hasanuddin \\ Makassar, Indonesia
}

\begin{abstract}
Hemangioma is a vascular benign tumor frequently found in childhood and about $30 \%$ manifests itself in head and neck areas. This lesion is frequently found in lip, tongue and buccal mucosal areas. Its etiology is conjectured to be related to the proliferation of abnormalities of endothelium cells. According to its type, hemangioma is divided into capillary, cavernous, and mixed hemangioma. Surgery is indicated in cases that cause complications. A case of hemangioma was reported in the lower lip of an eight-year-old girl. The patient accompanied by her parents visited the Special Dental Care Clinic, Department of Oral Surgery, Hasan Sadikin Hospital, Bandung, with the complaint of having reddish bruises on the lower lip, which impeded the speaking and masticating function. Before radiotherapy was performed at the Radiology Polyclinic, mouth preparation was provided for all his teeth first, for the purpose of improving oral hygiene and preventing focal infection present in the intraoral condition.
\end{abstract}

Keywords: lip hemangioma, mouth preparation, radiotherapy

\begin{abstract}
ABSTRAK
Hemangioma merupakan tumor jinak vaskuler yang sering dijumpai pada masa kanakkanak dan sekitar 30\% timbul di daerah kepala dan leher. Lesi ini sangat sering ditemukan pada daerah bibir, lidah, dan mukosa bukal. Etiologinya diduga berhubungan dengan abnormalitas proliferasi sel-sel endotelium. Hemangioma menurut jenisnya terbagi atas hemangioma kapiler, kavernosa, dan campuran. Penatalaksanaan dengan bedah diindikasikan pada kasus yang dapat menimbulkan komplikasi. Dilaporkan kasus hemangioma bibir bawah pada seorang anak perempuan usia 8 tahun. Pasien datang diantar orang tuanya ke Klinik Special Dental Care Bagian Bedah Mulut RS Hasan Sadikin, Bandung, dengan keluhan adanya benjolan kemerahan pada bibir kanan yang mengganggu fungsi bicara dan pengunyahan. Pada kasus ini, sebelum dilakukan tindakan radioterapi di Poliklinik Radiologi, terlebih dahulu dilakukan mouth preparation dengan tujuan memperbaiki oral hygiene dan pencegahan fokal infeksi yang ada pada kondisi intra oralnya.
\end{abstract}

Kata kunci: hemangioma bibir, mouth preparation, radioterapi

Koresponden: Harun Achmad, Bagian Ilmu Kedokteran Gigi Anak Fakultas Kedokteran Gigi Universitas Hasanuddin, Jl. Perintis Kemerdekaan Km.10 Tamalanrea, Makassar, Indonesia

\section{PENDAHULUAN}

Hemangioma merupakan salah satu tumor jinak dari sel-sel endotelium pembuluh darah yang lebih sering terjadi pada bayi dan anak-anak. Terdapat banyak pendapat para ahli mengenai definisi hemangioma, namun pada intinya 
mempunyai pengertian yang sama bahwa hemangioma adalah tumor yang berasal dari pembuluh darah yang bersifat kongenital dan terdiri dari hemangioma kapiler dan kavernosa. Hemangioma adalah tumor dari pembuluh darah, terdiri dari ruang vaskuler besar (kavernosa) atau terdiri dari banyak pembuluh darah kecil (kapiler), yang dapat terjadi pada semua organ atau jaringan tubuh, namun lebih sering berlokasi di kulit, jaringan subkutan dan membran mukosa rongga mulut dan bibir. Hemangioma merupakan malformasi yang bersifat kongenital dan sering timbul setelah masa kelahiran yang terbentuk dari sisa mesoderm pada perkembangan vaskuler. ${ }^{1,2}$

Hemangioma menurut insidensinya $1,1 \%$ sampai 2,6\% lebih banyak terjadi pada bayi dan $10 \%$ sampai $12 \%$ pada anak-anak di atas usia 1 tahun. Lebih sering terjadi pada wanita dibanding dengan pria dengan rasio 3:1. Berdasarkan lokasi lebih banyak ditemukan pada daerah kepala dan leher. Pada daerah rongga mulut sering ditemukan di bibir, lidah, dan mukosa bukal. Lesi ini dapat juga timbul di pipi, atau di palatum molle. Selain itu, juga dapat mengalami perluasan lokasi dan dapat mempengaruhi pengunyahan dan fungsi bicara. $^{3,4}$

Hemangioma diklasifikasikan menjadi hemangioma kavernosa, kapiler, dan campuran. Hemangioma kapiler dapat disubdivisikan menjadi hemangioma juvenil, hemangioma senil, nevus flammeus, dan granuloma piogenik. Hemangioma kapiler merupakan tumor pembuluh darah yang paling sering ditemukan, dan karena warnanya disebut juga hemangioma strawberry. Hemangioma juvenile lebih sering ditemukan di daerah parotis. Hemangioma kavernosa umumnya berdiameter lebih besar dan melibatkan struktur yang lebih dalam. Hemangioma arterivenosa merupakan suatu keadaan sehingga terjadi hubungan yang abnormal antara arteri dan vena., ${ }^{4,5}$
Kebanyakan dari hemangioma akan mengalami regresi (involusi) sesuai dengan perkembangan usia, namun pada beberapa keadaan proses regresi tersebut tidak terjadi secara total. Beberapa pilihan perawatan terhadap kasus hemangioma yaitu pembedahan dengan eksisi, pemberian obat-obatan seperti kortikosteroid, terapi cryo, terapi laser embolisasi, dan penyuntikan bahan sklerotik atau kombinasi dari perawatan tersebut di atas. ${ }^{5}$

Etiologi hemangioma masih belum jelas, namun ada tanda sisa-sisa penyimpangan dari pembentukan elemen jaringan pembuluh darah. Kebanyakan merupakan suatu malformasi perkembangan vaskuler selama perkembangan jaringan pembuluh darah. Beberapa literatur menyebutkan bahwa hemangioma bukan tumor sejati, bersifat kongenital, atau malformasi pembentukan vaskular karena traumatik, atau anomali saat perkembangannya. Beberapa lesi menunjukkan sebagai tumor, namun kemungkinan merupakan trauma saat pembentukan atau perkembangan pembuluh darah. Fokal infeksi dapat terjadi ketika mikroorganisme yang berasal dari gigi dan mulut menyebabkan infeksi atau penyakit di bagian tubuh yang lain. Infeksi di akar gigi maupun di jaringan periodontal melibatkan bakteri dan mikroorganisme. Ditemukan lebih dari 6 milyar mikroba tinggal dan hidup di dalam mulut, yang berasal lebih dari 500 strain yang berbeda. Mikroba yang terbanyak didapatkan adalah Candida albicans, Porphyromonas gingivalis, Streptococus mutans, Actinobacillus actinomycetemcomitans, Treponema denticola, dan Streptococcus sanguis. ${ }^{6,7}$

Pada makalah ini dilaporkan suatu penanganan mouth preparation kasus hemangioma pada bibir bawah kanan seorang anak usia 8 tahun yang dilakukan sebelum 
perawatan lebih lanjut dengan radioterapi di Poliklinik Radiologi.

\section{LAPORAN KASUS}

Seorang anak perempuan berusia 8 tahun datang ke Klinik Special Dental Care Rumah Sakit Hasan Sadikin Bandung atas rujukan dari Poli Radiologi untuk mencari fokal infeksi, yang penatalaksanaannya dilakukan sebelum tindakan pembedahan hemangioma pada bibirnya. Pasien didiagnosis dengan hemangioma pada mulut (angiofibroma) yang terdeteksi sejak usia balita. Saat ini pasien mengeluhkan keadaan bibirnya, karena mengganggu dalam pengunyahan, bicara dan estetik. Ia sehari-hari melihat posisi, dan ukuran lesi yang semakin membesar.

Pasien dirujuk dari Poli Radioterapi untuk pemeriksaan dan perawatan sebelum dilakukan radiasi tahap kedua karena terdapat benjolan pada pipi dan bibir kanan sejak lahir. Pasien pernah dioperasi pada usia 11 bulan dan telah dilakukan radiasi tahap pertama pada bulan April 2007.

Pada pemeriksaan fisik dan anamnesis didapatkan keadaan sebagai berikut:

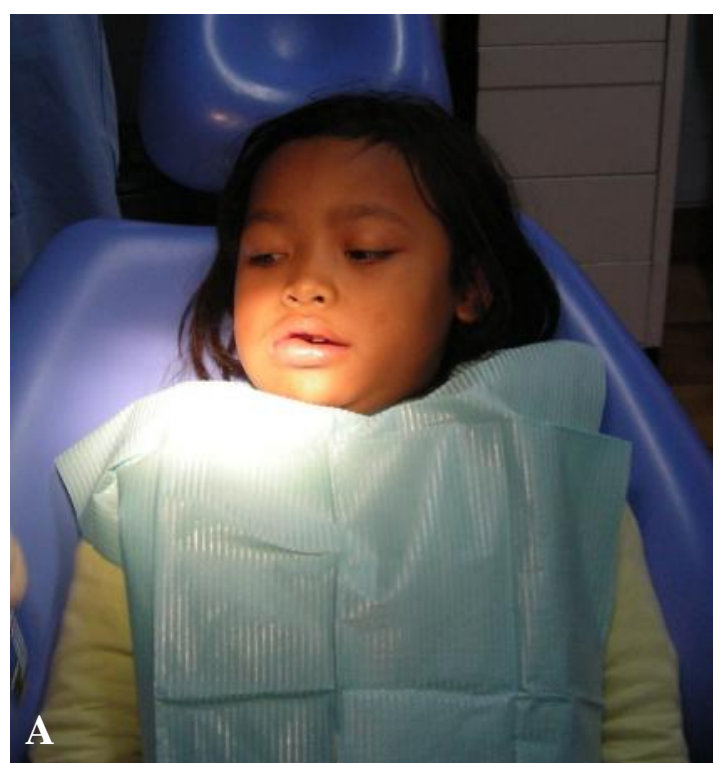

Gambar 1. A. Profil pasien sebelum tindakan mouth preparation, B. Penambalan gigi geligi pasien

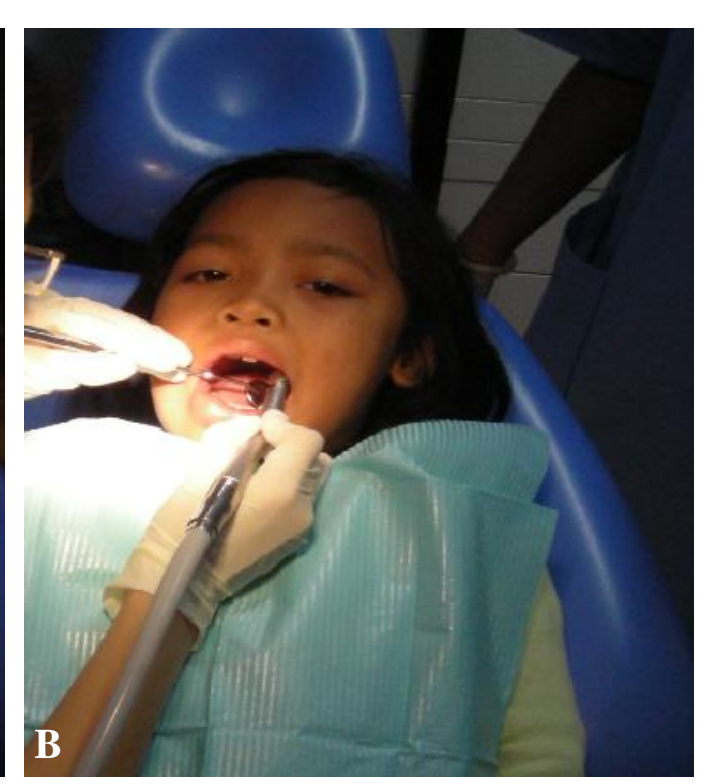

Keadaan umum: Terdapat pembengkakan pada pipi kanan (gambar 1A).

Riwayat Penyakit Umum: tidak ada. Pada pemeriksaan klinis didapatkan data sebagai berikut: pernapasan 20x/menit, denyut nadi $82 \mathrm{x} /$ menit, ekspresi muka tenang, suhu afebris, kelenjar limfe tidak teraba, dan tidak sakit.

Status lokalis ekstra oral: pembengkakan pada pipi dan bibir kanan, ukuran $\pm 5 \mathrm{~cm}$, permukaan licin, warna sama dengan jaringan sekitar, sifat terlokalisasi, ulkus tidak ada, konsistensi kenyal, fluktuasi tidak ada, nyeri tekan tidak ada. Sementara intra oral: mukosa labial terdapat pembengkakan pada regio kanan, ukuran $\pm 5 \mathrm{~cm}$, permukaan berbonjol-bonjol, warna sama dengan jaringan sekitar, sifat terlokalisasi, konsistensi kenyal, fluktuasi tidak ada, nyeri tekan tidak ada, krepitasi tidak ada. Diagnosis klinis gigi-geligi intra oral adalah gangren radiks gigi 54, 52, 51, 85; gangren pulpa gigi 62; iritasi pulpa gigi 75 , dan pulpitis reversibel gigi 55, 84, 36 .

Rencana perawatan adalah pro ekstraksi gigi 54, $52,51,62,85$ dan pro penambalan gigi $55,75,84$, 36 (gambar 1B). 


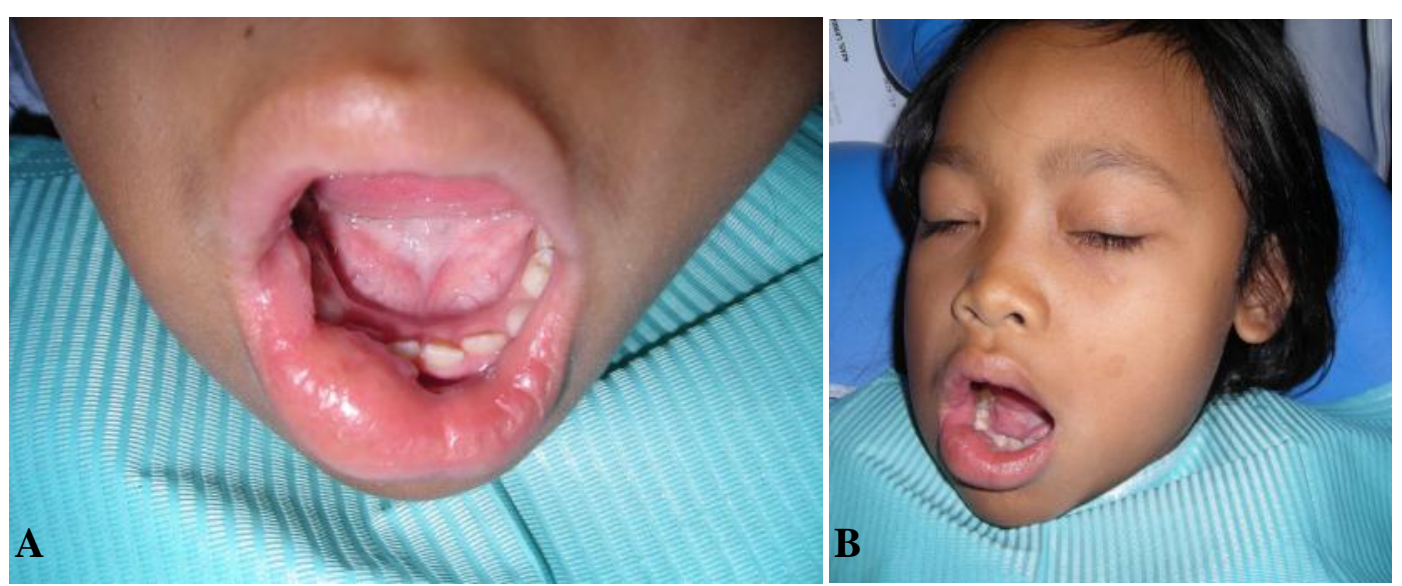

Gambar 2. Kondisi pasien setelah tindakan penambalan dan pencabutan A. intra oral, dan B. ekstra oral

\section{PEMBAHASAN}

Hemangioma merupakan suatu proliferasi yang terjadi pada sel-sel endotelium yang mulai terbentuk sejak usia bayi dan diikuti dengan involusi seiring dengan pertambahan usia. Beberapa hipotesis mengenai patofisiologi dari hemangioma menyatakan bahwa proses ini diawali dengan suatu proliferasi dari sel-sel endotelium yang belum teratur dan dengan perjalanan waktu menjadi teratur dengan membentuk pembuluh darah yang berbentuk lobus dengan lumen yang berisi sel-sel darah. Sifat pertumbuhan endotelium tersebut jinak dan memiliki membrana basalis yang tipis. ${ }^{3,4}$

Proliferasi tersebut akan melambat dan akhirnya berhenti. Pada trimester terakhir dari kehamilan di dalam fetus terbentuk endothelium immature bersama dengan pericyte yang juga immature yang memiliki kemampuan melakukan proliferasi terbatas dimulai pada usia 8 bulan sampai 18 bulan pertama masa kehidupan setelah dilahirkan. Pada masa demikian terbentuk hemangioma. Selama aktivitas proliferasi endotelium terjadi influks sejumlah sel mast dan tissue inhibitors of metalloproteinase (TIMP atau inhibitor pertumbuhan jaringan). Proliferasi endotelium kembali normal setelah fase proliferasi berhenti atau involusi. Sebagian besar hemangioma akan mengalami involusi spontan pada usia 5-7 tahun atau sampai usia 10-12 tahun. $^{4,5}$

Pemeriksaan penunjang dalam menegakkan diagnosis hemangioma dilakukan untuk mendiagnosis banding dengan kelainan lain seperti malformasi vaskuler atau limfangioma dapat dibantu dengan pemerikasaaan histopatologi, untuk mengklasifikasikan secara mikroskopis apakah tipe kapiler atau kavernosa. Pemeriksaan penunjang lain dengan imaging misalnya MRI dengan kontras, USG, CT-scan dan foto konvensional terutama pada hemangioma tulang. ${ }^{2,3}$ Diagnosis banding dari suatu hemangioma adalah malformasi vaskuler yang pada malformasi telah ada pada saat bayi dilahirkan, kelainan pada pembuluh darah serta adanya dilatasi dari arteri, vena dan kapiler, perkembangan progresi akan menetap (tidak mengalami regresi) dan umumnya bersifat rekuren. Diagnosis banding adalah limfangioma yang merupakan tumor yang berasal dari tumor limfe. ${ }^{5,6}$

Kebanyakan kasus hemangioma hanya membutuhkan waktu observasi sampai terjadi regresi (involusi) secara spontan. Tetapi pada 
keadaan tertentu, terutama jika ukurannya cukup besar dan mengganggu baik dari segi fungsi maupun estetik, hemangioma dapat dilakukan perawatan baik secara radikal dengan eksisi atau non-bedah. Perawatan dengan pembedahan memiliki keuntungan yang lebih baik dari segi estetik namun mempunyai resiko pendarahan serta memungkinkan terjadinya perluasan tumor. ${ }^{6-7}$

Terapi cryo yang juga dikenal dengan istilah bedah cryo merupakan suatu perawatan pilihan untuk hemangioma dan lesi-lesi kulit yang lain. Prinsip kerja dan terapi ini yaitu menyebabkan nekrosis dari sel yang diakibatkan oleh pembekuan dan melunaknya sel-sel. Daerah yang diterapi akan mengalami re-epitelisasi. Efek sampingnya kecil dan waktu terapinya singkat. Keuntungan lain dari terapi ini adalah prosedurnya mudah, biaya yang relatif murah serta hasil yang baik dari segi kosmetik untuk lesi-lesi kulit dan mukosa. ${ }^{7,8}$

Metode ini diperkenalkan pada tahun 1940-an dengan menggunakan cairan nitrogen yang diaplikasikan dengan kapas. Mekanisme kerja dari terapi cryo terbagi 3 tahapan, yaitu: (1) pemindahan panas adalah sel-sel target dirusak dengan memindahkan panas secara cepat. Cryogen yang digunakan adalah cairan nitrogen dengan suhu $-196{ }^{\circ} \mathrm{C}$. Dengan menggunakan probe maka panas akan terfokus pada lesi yang disesuaikan dengan probe yang ada, (2) kematian sel adalah terjadi setelah sel-sel yang membeku mengalami pelunakan. Perubahan dari konsentrasi air ke es pada ekstraseluler dan perubahan tekanan osmotik yang tinggi akan menyebabkan kerusakan sel, dan (3) inflamasi merupakan hasil akhir dari proses cryo dengan manifestasi berupa eritema dan oedema. Eritema dan oedema merupakan proses inflamasi. Proses inflamasi ini sebagai reaksi dari kematian sel dan membantu dalam merusak sel-sel yang terlibat. ${ }^{7,8}$
Terapi non-bedah yang lain adalah pemberian obat-obatan dapat berupa kortikosteroid atau interferon. Terapi kortikosteroid menurut beberapa penulis sebaiknya digunakan secara selektif dan bukan merupakan terapi utama dari hemangioma. Mekanisme yang diduga berhubungan dengan pemberian kortikosteroid adalah dengan menghambat reseptor estradiol-17 beta yang berperan dalam proliferasi hemangioma. Hipotesis lain diduga bahwa efek vasokonstruksi dari kortikosteroid berperan dalam hal ini terhadap penyusutan dari kapiler-kapiler pembuluh darah. ${ }^{8}$

Pada pasien ini benjolan mulai terlihat sejak lahir yang terus membesar sampai usia 8 tahun. Meskipun secara teori pada usia ini proses involusi akan mulai terjadi, namun karena pertimbangan estetik yaitu terlihat bibir yang tidak simetris lagi maka diharapkan dengan pemberian terapi akan mempercepat proses involusi.

Pada pasien ini dilakukan tindakan berupa pencabutan gigi untuk gigi-gigi 54, 52, 51, 62, dan 85 serta tindakan penambalan untuk gigi-gigi 55, 75, 84, dan 36 dengan menggunakan bahan tambal glass ionomer. Hal ini dilakukan sebagai tindakan pencegahan untuk kemungkinan terjadinya fokal infeksi yang dapat memperparah keadaan pasien atau terjadinya komplikasi lebih lanjut dari keadaan intra oralnya sebelum dilakukan tindakan radioterapi pada hemangioma bibir pasien bersangkutan.

\section{SIMPULAN}

Hemangioma merupakan tumor jinak rongga mulut terjadi karena proliferasi dari sel-sel endotelium pembuluh darah. Bibir merupakan lokasi hemangioma rongga mulut yang biasa ditemukan. Perawatan dari tumor ini dapat dilakukan dengan pembedahan seperti eksisi, dan perawatan non-bedah seperti pemberian terapi cryo, embolisasi, penyuntikan bahan sklerotik, 
pemberian preparat kortikosteroid dan interferon, serta terapi laser.

Kombinasi terapi cryo dengan pemberian preparat kortikosteroid merupakan terapi pilihan yang memberikan hasil yang cukup baik, namun pemberian preparat kortikosteroid sistemik harus mempertimbangkan efek samping kortikosteroid itu sendiri.

\section{DAFTAR PUSTAKA}

1. Mulliken JB. Cutaneus vascular anomalis. In: McCarthy JG (editor). Plastic surgery, vol.5. Philadelphia: W.B. Saunders Company; 1990. p. 3191-273.

2. Lin RL. Arterial vascular malformation including hemangiomas and lymphangiomas. Available at http/www.eMedicine.com. Accessed on May 19, 2004.
3. Wilk R. Oral hemangiomas. Available at http/www.eMedicine.com. Accessed on February 26, 2003.

4. Neville BW, Damm DD, Allen CM, Bouquet JE. 1995. Oral and maxillofacial pathology. Philadelphia: W.B. Saunders Company; 1995. p. 390-2.

5. Regesi JA, Sciubba JJ. Oral pathology: clinical pathology correlations. $3^{\text {rd }}$ ed. Philadelphia: W.B. Saunders Company; 1999. p. 122-8.

6. Yuwono HS. Hemangioma, sebuah pengantar dalam penatalaksanaan. J Persatuan Ahli Bedah Mulut Indonesia 2004; 8: 217-20.

7. Kuwahara RT. Cryotherapy. Available at http/www.eMedicine.com. Accessed on January 6; 2003.

8. Blei F, Chianeese J. Corticosteroid toxicity in infants treated for endangering hemangiomas: experience and guidelines for monitoring. $\mathrm{J}$ Int Pediatr 1999; 14 (3): 146-53. 